\title{
PENTINGNYA ETIKA BERBICARA DALAM PERSPEKTIF ISLAM BAGI MAHASISWA MILLENIAL
}

\author{
Nurrul Khasanah ${ }^{1 *}$ \\ Yoan Indah Lestari ${ }^{2}$ \\ Sophia Nuraini ${ }^{3}$ \\ Andi Luthfiyyah I.D ${ }^{4}$ \\ Ani Nur Aeni ${ }^{5}$ \\ 1,2,3,4,5Universitas Pendidikan Indonesia, Sumedang, Indonesia \\ nurrulkh30@upi.edu ${ }^{\left.1^{*}\right)}$ \\ yoanindahl18@upi.edu ${ }^{2}$ \\ sophianur@upi.edu ${ }^{3)}$ \\ aandiluthfi@upi.edu ${ }^{4}$ \\ aninuraeni@upi.edu ${ }^{5}$
}

Kata Kunci:

[Etika Berbicara, mahasiswa, perspektif Islam]

Published by:

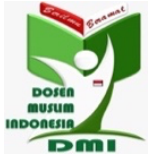

Penyuluhan ini bertujuan untuk memberikan kesadaran bahwa pentingnya etika berbicara dalam perspektif Islam bagi mahasiswa millenial. Adapun etika berbicara dalam perspektif Islam yaitu: 1) Jujur dalam berkata, 2) Melihat wajah atau mata lawan bicara, 3) Berbicara yang baik atau diam, 4) Tidak menggunjing (Ghibah), 5) Tidak memotong pembicaraan, 6) Menunjukan sikap antusias saat berbicara, 7) Berusaha menghindari perdebatan, 8) Menghindari perkataan sarkasme (berkata kasar) dan Perkataan kotor. Pelaksanaan penyuluhan ini dilakukan secara online melalui video conference zoom meeting pada hari Senin, 01 November 2021, pukul 13.00 WIB s/d selesai. Partisipan penyuluhan ini sebanyak 44 partisipan dengan 21 diantaranya sebagai responden. Hasil penyuluhan menunjukan bahwa ada 21 responden yang mengisi angket dari 44 partisipan dengan 95,2\% mahasiswa 4,8\% umum, penyuluhan ini memberikan kesadaran akan pentingnya etika berbicara dalam perspektif Islam dengan hasil 100\% partisipan menjawab "Ya", materi yang disampaikan mengenai etika berbicara dalam perspektif Islam ini $95,2 \%$ responden menjadi tahu bagaimana cara berbicara yang baik dan santun dalam pandangan agama Islam, dan sebesar $14,3 \%$ responden menyatakan bahwa berbicra dengan santun masih sulit untuk diimplementasikan.

Copyright (C) 2021 The Author(s)

This article is licensed under CC BY 4.0 License (cc) EY 


\section{Pendahuluan}

Etika berasal dari bahasa Yunani yaitu ethos yang berarti adat istiadat (kebiasaan), perasaan batin, kecenderungan hati untuk melakukan perbuatan atau mengajarkan tentang keluhuran budi baik-buruk. Sedangkan menurut Maryani dan Ludigdo, etika adalah seperangkat norma, aturan atau pedoman yang mengatur segala perilaku manusia, baik yang harus dilakukan ataupun yang harus ditinggalkan yang dianut oleh sekelompok masyarakat atau segolongan masyarakat. Dengan itu, dapat disimpulkan bahwa etika sangat erat kaitannya dengan peraturan, adab, dan pedoman tentang tingkah laku manusia. Pada hakikatnya, etika tidak hanya tentang adab berperilaku dalam kehidupan sehari-hari, akan tetapi etika juga dapat berkaitan dengan adab bertutur kata yang baik, benar, dan santun, seperti misalnya etika berbicara atau berkomunikasi dengan orang lain. Namun dalam kenyataannya, di zaman sekarang ini masih banyak anak muda atau mahasiswa yang masih belum menerapkan etika berbicara yang baik dan benar menurut ajaran agama Islam. Seperti, misalnya sering tidak berkata jujur, menggunjing orang lain, dan berkata kotor. Maka dari itu, kami mengadakan penyuluhan dengan judul "PENTINGNYA ETIKA BERBICARA DALAM PERSPEKTIF ISLAM BAGI MAHASISWA MILLENIAL". Dalam agama Islam, etika berbicara pun menjadi hal yang harus diperhatikan. Seperti dalam kisah Rasulullah SAW yang terkenal dengan kelembutannya saat berbicara, sehingga banyak yang merasa dimuliakan oleh Beliau. Etika berbicara dijelaskan dalam Alquran surat Al-Baqarah ayat 263, yaitu:

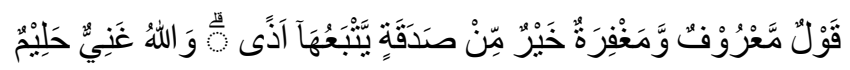

Artinya: Perkataan yang baik dan pemberian maaflebih baik daripada sedekah yang diiringi tindakan yang menyakiti. Allah Maha Kaya, Maha Penyantun.

M. Quraish Shihab dalam buku Tafsir Al Misbah menafsirkan ayat tersebut dengan arti lebih baik memberi sesuatu tanpa berkata apa pun, daripada memberi tetapi memaki-makinya setelahnya. Oleh karena itu, etika dalam berbicara sangatlah penting untuk diterapkan dalam kehidupan sehari-hari apalagi kita sebagai mahasiswa yang disebut sebagai Agen of Change harus bisa bertutur kata dengan baik untuk menjadi contoh yang baik.

Penyuluhan ini bertujuan untuk memberikan kesadaran bahwa pentingnya etika berbicara dalam perspektif Islam bagi mahasiswa millenial. Adapun rumusan masalah yang diambil dalam penyuluhan ini yaitu; 1) Bagaimana pentingnya etika berbicara dalam perspektif Islam bagi mahasiswa? dan 2) Apa saja etika berbicara dalam perspektif Islam yang masih sulit diterapkan oleh Mahasiswa?

\section{Metode Pelaksanaan}

Pelaksanaan penyuluhan ini dilakukan secara online melalui video conference zoom meeting pada hari Senin, 01 November 2021, pukul 13.00 WIB s/d selesai. Penyuluhan ini dilakukan secara online karena melihat kondisi yang tidak memungkinkan untuk bertatap muka secara langsung, karena masih dalam situasi pandemi covid-19. Penyuluhan ini diawali dengan proses penyampaian materi, kemudian penyebaran angket kuesioner di akhir penyuluhan. Kegiatan penyuluhan ini tidak dipungut biaya sepeserpun (gratis), hanya dengan mendaftarkan diri melalui link 
yang sudah disediakan. Adapun rincian alur pelaksanaan sebagai berikut (Lihat Gambar 1).

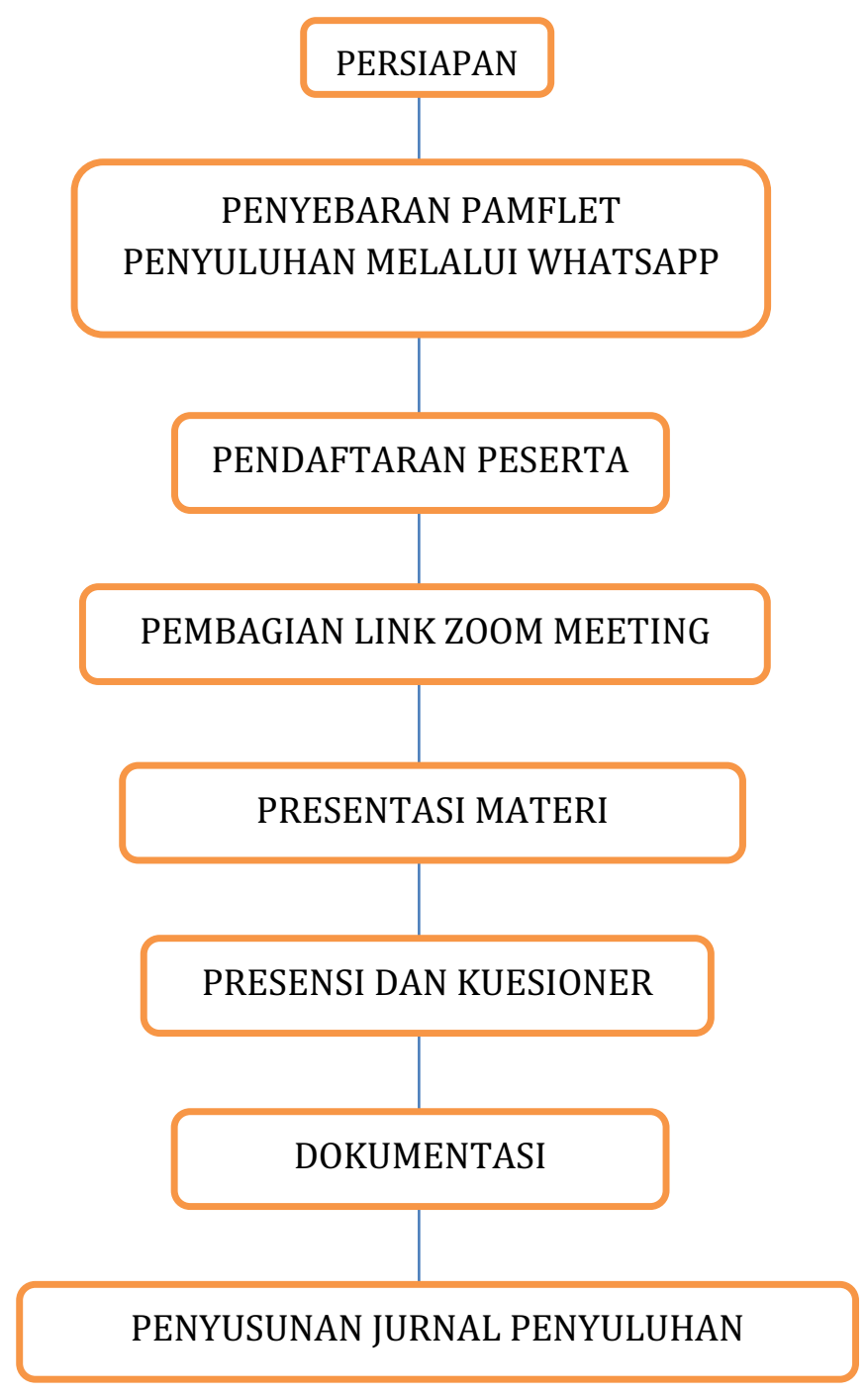

Gambar 1. Alur Pelaksanaan Kegiatan

Adapun kegiatan penyuluhan ini kami lakukan kepada para mahasiswa UPI Kampus Sumedang dan umum. Dengan total partisipan sebanyak 44 orang, dengan 21 diantaranya sebagai responden angket kuesioner. Penyuluhan dilakukan dengan pemaparan materi terkait "PENTINGNYA ETIKA BERBICARA DALAM PERSPEKTIF ISLAM BAGI MAHASISWA MILLENIAL”. 


\section{Hasil dan Pembahasan}

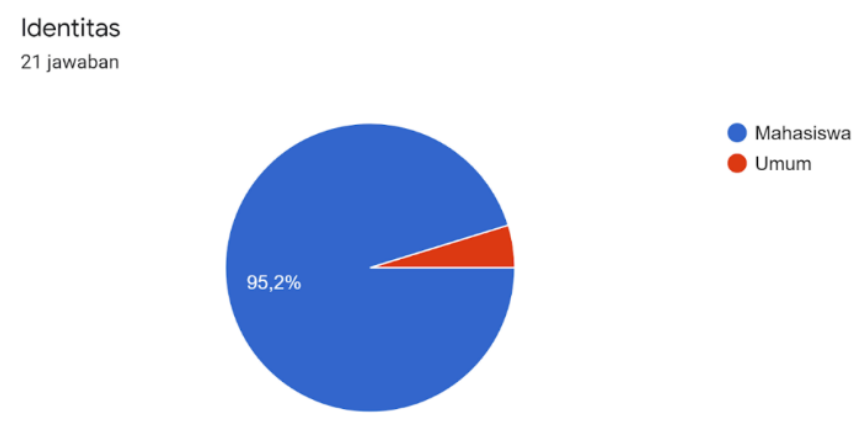

Gambar 2. Gambaran Peserta Kegiatan

Hasil penyuluhan menunjukan bahwa ada 21 responden yang mengisi angket dari 44 partisipan dengan 95,2\% mahasiswa 4,8\% umum.

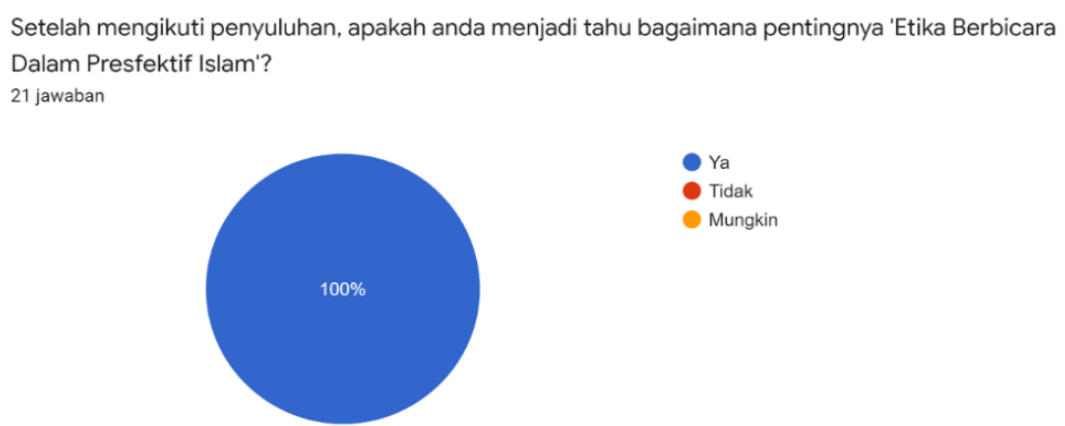

Gambar 3. Hasil Angket Respon Pentingnya Etika Berbicara dalam Presfektif Islam

Hasil penyuluhan menunjukan bahwa seluruh responden memberikan respon bahwa penyuluhan ini memberikan kesadaran akan pentingnya etika berbicara dalam perspektif Islam dengan hasil 100\% partisipan menjawab "Ya".

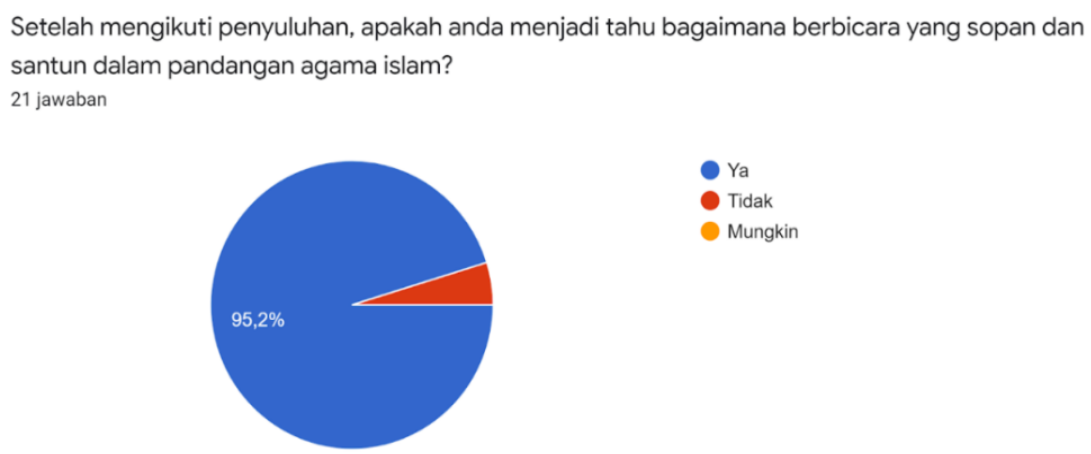

Gambar 4. Hasil Angket Respon Cara Berbicara yang Sopan dan Santun dalam Pandangan Islam 
Hasil penyuluhan menunjukan bahwa materi yang disampaikan mengenai etika berbicara dalam perspektif islam ini $95,2 \%$ responden menjadi tahu bagaimana cara berbicara yang baik dan santun dalam pandangan agama Islam.

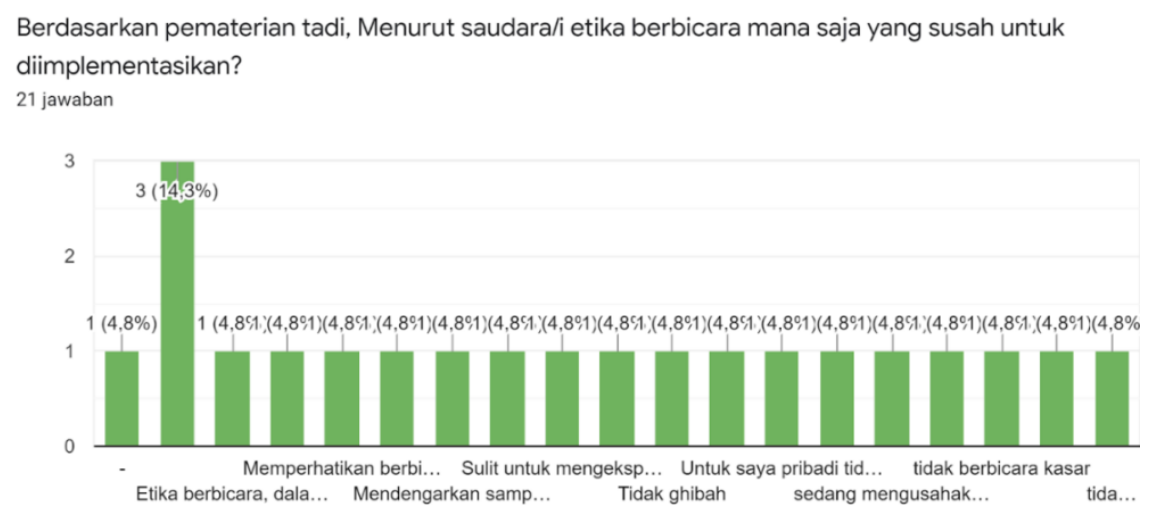

Gambar 5. Hasil Angket Respon Etika Berbicara yang Susah Diimplementasikan

Hasil penyuluhan menunjukan bahwa sejumlah 14,3\% responden menyatakan bahwa menyusun kalimat dengan ucapan santun masih sulit untuk diimplementasikan.

Berdasarkan hasil dari hasil kuesioner tersebut bahwa seperti yang kita ketahui, disamping adanya Hablumminallah, di situ pula ada Hablumminannas. Artinya, selain adanya hubungan kita dengan yang Maha kuasa, yakni Allah SWT. Ada pula hubungan yang tak kalah pentingnya yakni hubungan kita dengan sesama manusia yang lain. Hubungan yang terjalin antara manusia dengan manusia lain tentu tidak akan lepas dengan yang namanya berkomunikasi verbal atau berkomunikasi secara lisan. Karena, setiap penyampaian informasi, pesan, ataupun perasaan pastinya akan lebih mudah dan sering kita sampaikan atau ungkapkan dengan lisan kita. Oleh karena itu, kita sesama manusia hendaknya memperhatikan etika dan adab dalam berbicara, sehingga apa yang sampaikan atau katakan tidak akan menyinggung dan membuat sakit hati lawan bicara kita. Kemudian, kita sebagai mahasiswa. Dimana pasti akan berinteraksi dan berkomunikasi dengan secara lebih luas, karena notabenenya sedang membangun banyak relasi dengan orang lain. Tentu, sangat perlu memperhatikan adab atau etika ketika sedang berbicara. Baik itu saat berbicara dengan dosen, teman sekelas, teman organisasi, dan dengan pihak-pihak tertentu dalam sebuah kegiatan. Penting sekali memahami adab atau etika dalam berbicara. Adapun dalam islam ada 8 etika berbicara yang perlu diperhatikan bagi seorang muslim, diantaranya yaitu:

\section{Jujur dalam Berbicara}

Al-Qur'an, QS. Al-Ahzab, ayat 70 Allah SWT berfirman: "Hai orang-orang yang beriman, bertakwalah kamu kepada Allah dan katakanlah perkataan yang benar". Dengan adanya ayat tersebut, menunjukkan bahwa kita sebagai seorang muslim, seseorang yang beriman kepada Allah, hendaklah berbicara yang baik dan benar sesuai kenyataannya dan kebenarannya. Jangan sampai kita berbicara hal-hal yang tidak baik dan tidak benar kenyataannya atau sama dengan halnya berbohong. Kemudian, Jujur pula merupakan salah satu sifat Rasulullah SAW yang harus kita teladani. Karena, 
dengan kita selalu berkata jujur, akan dapat banyak manfaat yang kita peroleh. Seperti dengan jujur kita akan terhindar dari dosa, akan dapat lebih dipercaya oleh semua orang, dan pastinya kita akan termasuk ke dalam orang-orang yang beriman dan bertaqwa kepada Allah.

\section{Melihat Wajah atau Mata Lawan Bicara}

Hal ini penting kita lakukan karena lawan bicara kita akan merasa lebih dihargai dan dihormati keberadaannya oleh kita. Sehingga, saat berbicara kita dianggap menyimak dan memperhatikan apa yang disampaikan dan diutarakan oleh lawan bicara kita, dan tidak seolah-olah mengabaikannya.

\section{Berbicara yang Baik atau Diam}

Berbicara hendaknya kita memikirkan terlebih dahulu apa yang akan kita sampaikan. Apakah pesan yang akan kita sampaikan ini baik atau tidak, bermanfaat atau tidak, santun atau tidak. Jangan sampai apa yang kita sampaikan, akan menimbulkan hal-hal yang kurang mengenakan. Seperti, akan dapat menyakiti hati atau perasaan lawan bicara kita, perkataan yang kotor atau kurang pantas untuk kita sampaikan, dan lain-lain. Oleh karena itu, kita haruslah berbicara yang baik dan bermanfaat, bila kita tidak bisa melakukannya, maka lebih baik kita diam saja.

\section{Tidak Menggunjing (Ghibah)}

Seorang muslim dalam berbicara diusahakan tidak menggunjing, membicarakan kesalahan orang lain. Atau sampai pula mengajak lawan bicara kita untuk benci dan berburuk sangka pada orang lain. Usahakan, kita berbicara yang baik-baik tentang orang lain, jangan sampai menghasut dan menebar kebencian pada orang lain. Karena, Ghibah atau menggunjing itu hanya akan mengalirkan pahala kita kepada orang yang kita bicarakan, sementara kita hanya akan mendapatkan dosa.

Al-Qur'an, QS. Al- Hujurat, ayat 12, Allah berfirman: "Hai orang-orang yang beriman, jauhilah kebanyakan purba-sangka (kecurigaan), karena sebagian dari purbasangka itu dosa. Dan janganlah mencari-cari keburukan orang dan janganlah menggunjingkan satu sama lain. Adakah dari seorang diantara kamu yang suka memakan daging saudaranya yang sudah mati. Maka, tentulah kamu merasa jijik kepadanya. dan bertakwalah kepada allah". Dengan adanya ayat tersebut, menegaskan bahwa menggunjing atau menggibah orang lain hanya akan mendapat dosa saja, dan tidak akan ada manfaatnya sama sekali. Karena sesungguhnya, salah satu penyumbang dosa terbesar manusia adalah lisannya.

\section{Tidak Memotong Pembicaraan}

Memotong pembicaraan orang lain merupakan salah satu ciri orang yang tidak memiliki kesopanan. Selain itu, memotong pembicaraan orang lain juga dapat mengubah, menghilangkan informasi yang akan disampaikan sehingga bisa saja orang yang sedang berbicara tersebut lupa apa yang sedang dibicarakan dan juga dapat menimbulkan kesalahpahaman. Maka dari itu, saat ada orang lain berbicara sebaiknya tunggu lawan bicara selesai menyampaikan apa yang disampaikan setelah itu barulah kita tanggapi jika perlu untuk ditanggapi. Seperti Al-Hasan Al-Bashri berkata yang artinya: "Apabila engkau sedang duduk berbicara dengan orang lain, hendaknya engkau 
bersemangat mendengar melebihi semangat engkau berbicara. Belajarlah menjadi pendengar yang baik sebagaimana engkau belajar menjadi pembicara yang baik. Janganlah engkau memotong pembicaraan orang lain." (Al Muntaqa hal. 72).

\section{Menunjukan Sikap Antusias saat Berbicara}

Menunjukan sikap antusias saat berbicara perlu dilakukan sebagai bentuk menghargai apa yang mereka bicarakan, meskipun pembicaraan tersebut sudah pernah didengar sebelumnya. Maka dari itu, sangat diperlukan sikap saling memahami antara pembicara dan lawan bicaranya. Seperti Ataa' bin Abi Rabah berkata yang artinya: "Ada seseorang laki-laki menceritakan kepadaku suatu cerita, maka aku diam untuk benarbenar mendengarnya, seolah olah aku tidak pernah mendengar cerita itu, padahal sungguh aku pernah mendengar cerita itu sebelum ia dilahirkan." (Siyar A'laam AnNubala 5/86).

\section{Berusaha Menghindari Perdebatan}

Perdebatan merupakan suatu perbuatan yang biasa terjadi namun harus dihindari karena saat terjadi perdebatan bisa memicu timbulnya rasa sakit hati satu dengan yang lainnya. Maka dari itu ketika terjadi perbedaan harus diselesaikan dengan cara bermusyawarah dan berbicara dengan baik dan hati-hati supaya tidak terjadi perdebatan yang panjang. Sebagaimana Nabi Muhammad SAW bersabda yang artinya: "Aku menjamin sebuah istana di sekitar surga bagi siapa saja yang meninggalkan perdebatan walaupun dia dalam keadaan benar. Dan di pertengahan surga bagi seorang yang meninggalkan kedustaan walau dalam bercanda dan di bagian surga tertinggi bagi yang terpuji akhlaknya." (HR. Abu Dawud, dalam sunannya, no 4167).

\section{Menghindari Perkataan Sarkasme (Berkata Kasar) dan Perkataan Kotor}

Perkataan yang kasar dan ucapan yang menyakitkan perasaan seperti cacian dan sindiran sangat tidak dianjurkan oleh Rasulullah SAW. Karena perkataan tersebut bisa jadi pemicu dan mengundang kebencian, permusuhan, dan pertentangan. Begitupun dengan perkataan kotor yang mengatakan sumpah serapah, sindiran, kritikan tanpa ada dasar yang jelas merupakan perkataan yang harus dihindari, karena dengan berbicara seperti itu seperti memandang rendah lawan bicara. Berkata kotor juga tidak baik untuk diri sendiri karena kata-kata buruk mengandung energi negatif, yang jika dipelihara bisa berdampak buruk pada kondisi mental dan pikiran kita.

Al Imam Tirmidzi meriwayatkan dalam Sunnahnya, dimana Rasulullah SAW bersabda: "Sesungguhnya tidak ada sesuatu apapun yang paling berat ditimbangan kebaikan seorang mu'min pada hari kiamat seperti akhlak yang mulia, dan sungguhsungguh (benar-benar) Allah benci dengan orang yang lisannya kotor dan kasar." (Hadits Riwayat At Tirmidzi nomor 2002, hadits ini hasan shahih, lafadz ini milik At Tirmidzi, lihat Silsilatul Ahadits Ash Shahihah No 876).

\section{Kesimpulan}

Kesimpulan dari penyuluhan ini adalah sebagai berikut:

1. Hasil penyuluhan menunjukan bahwa ada 21 responden yang mengisi angket dari 44 partisipan dengan 95,2\% mahasiswa 4,8\% umum 
2. Hasil penyuluhan menunjukan bahwa seluruh responden memberikan respon bahwa penyuluhan ini memberikan kesadaran akan pentingnya etika berbicara dalam perspektif Islam dengan hasil 100\% partisipan menjawab "Ya"

3. Hasil penyuluhan menunjukan bahwa materi yang disampaikan mengenai etika berbicara dalam perspektif Islam ini 95,2\% respoden menjadi tahu bagaimana cara berbicara yang baik dan santun dalam pandangan agama Islam

4. Hasil penyuluhan menunjukan bahwa sebesar $14,3 \%$ responden menyatakan bahwa berbicra dengan santun masih sulit untuk diimplementasikan.

\section{Referensi}

Habibah, S. (2015). Akhlak Dan Etika Dalam Islam. Jurnal Pesona Dasar, 1(4), 73-87.

Hakis. (2020). Adab bicara dalam prespektif komunikasi islam. Jurnal Mercusuar, 1(1), 23.

Hukum, F., Esa, U., Tomang, T., \& Jeruk, K. (2017). Upaya Meningkatkan Adab Dan Etika Bicara Secara. 3, 98-103.

Mulyasana, D. (2019). Konsep Etika Belajar dalam Pemikiran Pendidikan Islam Klasik. Tajdid, 26(1), 100. https://doi.org/10.36667/tajdid.v26i1.319

Yanny, A., \& Hutabarat, S. A. (2021). Pembelajaran Etika Berkomunikasi Menggunakan Media Sosial Untuk Menghindari Konflik Di Masyarakat Bagi Siswa Siswi SMP Citra Harapan Percut. 2(1), 24-27. 